\title{
Pengaruh ekspor minyak mentah batu bara dan gas alam terhadap penyerapan tenaga kerja sektor pertambangan di Indonesia
}

\author{
Emilia; Candra Mustika* \\ Prodi Ekonomi Pembangunan Fakultas Ekonomi dan Bisnis Universitas Jambi \\ *E-mail korespondensi: candra.mustika@yahoo.com
}

\begin{abstract}
This study aims to analyze: 1) the development of Indonesian labor absorption in the mining sector, and the development of export commodities for crude oil, coal and natural gas; 2) the effect of exports of crude oil, coal and natural gas on employment absorption in the mining sector. The results of the study found that the absorption of Indonesian workers in the mining sector tended to increase by an average of $4.45 \%$, the volume of crude oil exports tended to decline by an average of $-5.96 \%$, coal commodities tended to increase with an average growth of $14.49 \%$ and the volume of export of natural gas commodities tends to increase with an average of $79.54 \%$. Based on the regression results show that the export volume of coal commodities has a significant positive effect and the volume of exports of natural gas commodities has a significant negative effect on employment in the mining sector. On the contrary, the export volume of crude oil commodities has no significant effect on employment in the mining sector.
\end{abstract}

Keywords: Labor, the mining, crude oil, coal, natural gas, exports

\begin{abstract}
Abstrak
Penelitian ini bertujuan untuk menganalisis: 1) perkembangan penyerapan tenaga kerja Indonesia di sektor pertambangan, dan perkembangan komoditas ekspor minyak mentah, batubara dan gas alam; 2) pengaruh ekspor minyak mentah, batubara dan gas alam terhadap penyerapan tenaga kerja disektor pertambangan. Hasil penelitian menemukan bahwa penyerapan tenaga kerja Indonesia di sektor pertambangan cenderung mengalami peningkatan dengan rata-rata $4,45 \%$, volume ekspor minyak mentah cendrung mengalami penurunan dengan rata-rata sebesar $-5,96 \%$, komoditas batubara cendrung mengalami peningkatan dengan rata-rata pertumbuhan sebesar $14,49 \%$ dan volume ekspor komoditas gas alam cendrung mengalami peningkatan dengan rata-rata sebesar 79,54\%. Berdasarkan hasil regresi menunjukkan bahwa volume ekspor komoditas batubara berpengaruh positif signifikan dan volume ekspor komoditas gas alam berpengaruh negatif signifikan terhadap penyerapan tenaga kerja di sektor pertambangan. Sebaliknya volume ekspor komoditas minyak mentah tidak berpengaruh signifikan terhadap penyerapan tenaga kerja di sektor pertambangan.
\end{abstract}

Kata kunci: Tenaga kerja, pertambangan, minyak mentah, batubara, gas alam, ekspor

\section{PENDAHULUAN}

Keadaan makro ekonomi suatu Negara dapat dilihat dari beberapa indikator antara lain adalah meningkatnya pertumbuhan ekonomi, pendapatan perkapita, dan turunnya angka kemiskinan dan pengangguran, setiap Negara berupaya untuk mengendalikan 
masalah ekonomi makro yang dihadapinya yang antara lain adalah masalah pengangguran, pengangguran adalah masalah yang sering sekali dihadapi oleh berbagai Negara di dunia ini terutama Negara miskin dan Negara yang sedang berkembang, dan Indonesia adalah termasuk Negara yang saat ini sedang giatnya membangun ekonominya dengan harapan dapat mensejahterakan rakyat dengan menekan angka kemiskinan dan pengangguran, banyaknya lapangan kerja yang tersedia merupakan salah satu cara untuk mengurangi angka pengangguran.

Indonesia yang memiliki sumber daya alam yang potensial karena keadaan alamnya yang memiliki iklim tropis dan kaya akan aneka ragam hayati sehingga banyak sekali lahan pertanian dan perkebunan sehingga banyak sekali penduduknya yang bekerja di sektor pertanian, namun selain itu banyak sekali kekayaan yang tersimpan di dalam bumi dan laut Indonesia yang jika dimanfaatkan dengan baik dapat digunakan untuk kesejahteraan rakyat Indonesia dengan terciptanya lapangan kerja di sektor pertambangan.

Jika dibandingkan dengan sektor pertanian yang dianggap kurang produktif dalam mengangkat taraf hidup maka sektor pertambangan dengan potensi penerimaan yang cukup besar diharapkan dapat menyerap tenaga kerja yang lebih besar sehingga rakyat Indonesia mayoritas tidak bekerja di sektor pertanian saja.

Perdagangan luar negeri memiliki pengaruh langsung dan tidak langsung terhadap perekonomian suatu Negara. Pengaruh langsung dari perdagangan luar negeri yaitu meningkatkan pendapatan masyarakat dan menciptakan kesempatan kerja. Sedangkan pengaruh tidak langsung dari perdagangan internasional yaitu sebagai penghasil devisa, transfer teknologi, dan sebagai transfer modal dari luar negeri (Haryadi, 2007).

Realisasi penerimaan negara dari sektor migas dalam beberapa tahun terakhir selalu melebihi target yang ditetapkan dalam Anggaran Pendapatan dan Belanja Negara (APBN). Meski saat ini Indonesia adalah negara net-importir, kontribusi penerimaan negara dari sektor migas cukup besar. Secara rata-rata, dari tahun 2011-2015, penerimaan negara dari sektor Migas yang meliputi PPh Migas, PNBP Migas dan PNBP lainnya dari kegiatan hulu migas berkontribusi pada penerimaan negara sebesar 21,61 persen.

Minyak mentah, Batu bara dan Gas alam adalah energi yang sangat dibutuhkan oleh setiap Negara di dunia ini, dan Indonesia adalah salah satu Negara yang memiliki tambang dan banyak mengundang investor asing, Minyak mentah memiliki kontribusi yang cukup besar bagi total nilai ekspor migas Indonesia, dimana pada tahun 2013 minyak mentah memiliki kontribusi sebesar 31,27 persen dari total ekspor migas Indonesia. Kemudian pada tahun 2014 minyak mentah memiliki kontribusi sebesar 30,7 persen, diikuti oleh tahun 2015 dimana minyak mentah memiliki kontribusi sebesar 34,8 persen dari total nilai ekspor migas Indonesia. Pada tahun 2015 ekspor batubara Indonesia mencapai 328.387 ribu metrik ton. Dan ekspor gas alam pada tahun 2014 mencapai 568.124 tera joul.

Komoditas ekspor minyak mentah, batubara dan gas alam yang terus meningkat diharapkan dapat membantu peningkatan penyerapan tenaga kerja di sektor pertambangan.

Keberhasilan pembangunan ekonomi salah satunya dipengaruhi oleh faktor produksi. Faktor-faktor produksi tersebut diantaranya adalah penduduk (sumber daya manusia). Yang dimaksud dengan sumber daya manusia adalah penduduk dalam usia kerja. Dari segi penduduk sebagai faktor produksi maka tidak semua penduduk dapat bertindak sebagai faktor produksi hanya penduduk usia kerja dalam arti sudah bekerja atau mencari kerja. Sedangkan kelompok bukan angkatankerja meliputi golongan yang bersekolah, golongan yang mengurus rumah tangga dan golongan-golongan lain atau penerima pendapatan yaitu mereka yang menerima pensiunan, tingkat bunga atas simpanan, sewa atas milik dan mereka yang hidupnyatergantung kepada orang lain 
seperti manula, penyandang cacat, narapidanaserta penderita sakit kronis (Irawan dan Suparmoko, 1992:67 dalam Pratama Diyan 2012) Menurut Sidjiatmo Kusumawidho (1998:53) dalam Pratama Diyan 2012 tenaga kerja adalah seluruh penduduk suatu negara yang dapat memproduksi barang dan jasa, jika ada permintaan terhadap tenagakerja dan jika mereka mau berpartisipasi dalam aktivitas tersebut. Menurut Payaman J. Simanjuntak (1985:2) dalam bukunya Pengantar Ekonomi Sumber Daya Manusia dalam Pratama Diyan 2012, tenaga kerja (man power) adalah penduduk yang sudah bekerja dan sedang bekerja, yang sedang mencari pekerjaan, dan yang sedang melaksanakan kegiatan lain seperti bersekolah dan mengurus rumah tangga. Orang tersebut dapat dikatakan sebagai angkatan kerja kecuali mereka yang tidak melakukan aktifitas kerja.

Menurut Undang-undang No. 13 Tahun 2003 Pasal 1, Tenaga Kerja adalah tiap orang yang mampu melaksanakan pekerjaan baik didalam maupun diluar hubungan kerja guna menghasilkan barang dan jasa untuk memenuhi kebutuhan masyarakat. Tenaga kerja adalahsebagian dari seluruhan penduduk yang secara potensial dapat menghasilkan barang dan jasa dari penduduk (Ananta,1986:286 dalam Pratama Diyan 2012). Pengertian Kesempatan Kerja Menurut Badan Pusat Statistik (2003;57) yang dimaksud kesempatan kerja adalah banyaknya orang yang dapat tertampung untuk bekerja pada suatu perusahaan. Kesempatan kerja ini akan menampung semua tenaga kerja apabila lapangan pekerjaan yang tersedia mencukupi atau seimbang dengan banyaknya tenaga kerja yang ada. Adapun lapangan pekerjaan adalah bidang kegiatan usaha, instansi dimana seseorang bekerja atau pernah bekerja. Menurut Dwi Janarko (1995:8) dalam Pratama Diyan 2012 kesempatan kerja merupakan kesempatan bagi angkatan kerja untuk menciptakan lapangan pekerjaan dengan harapan untuk mendapat imbalan yang dilakukannya. Usaha perluasan kesempatan kerja tidak terlepas dari faktor-faktor yang mempengaruhinya,

Teori permintaan menerangkan tentang ciri hubungan antara jumlah permintaan dengan harga. Sehubungan dengan tenaga kerja, permintaan tenaga kerja berarti hubungan antara tingkat upah dengan kuantitas tenaga kerja yang dikehendaki oleh majikan (pengusaha) untuk dipekerjakan (dibeli). Permintaan pengusaha atas tenaga kerja berlainan dengan permintaan konsumen terhadap barang dan jasa. Orang membeli barang dan jasa karena barang dan jasa tersebut memberikan nikmat kepada si pembeli. Sementara pengusaha mempekerjakan seseorang karena orang tersebut membantu memproduksi barang dan jasa untuk dijual kepada masyarakat konsumen. Dengan kata lain, pertambahan permintaan perusahaan terhadap tenaga kerja bergantung pertambahan permintaan masyarakat akan barang dan jasa yang diproduksi. Permintaan tenaga kerja yang seperti itu dinamakan derived demand (Payaman J. Simanjuntak, 1985:55 dalam Pratama Diyan 2012).

Pengusaha memperkerjakan seseorang karena membantu memproduksi barang/jasa untuk dijual kepada konsumen. Oleh karena itu, kenaikan permintaan pengusaha terhadap tenaga kerja, tergantung dari kenaikan permintaan masyarakat akan barang yang diproduksi. Ekspor adalah kegiatan memperdagangkan barang kepada penduduk negara lain ditambah dengan jasa-jasa yang diselenggarakan kepada penduduk negara tersebut berupa pengangkutan kapal, permodalan, dan lain-lain. Bagi banyak negara, khusunya Indonesia ekspor mempunyai peranan yang sangat penting yakni sebagai motor pembangunan ekonomi dan penggerak perekonomian nasional dikarenakan ekspor sebagai sumber penghasil devisa bagi negara. Devisa merupakan masuknya uang asing ke negara kita, yang dapat digunakan untuk membayar pembelian atas impor barang dan jasa dari luar negeri. Pentingnya ekspor bagi perekonomian negara berkembang termasuk Indonesia dapat dilihat dari manfaat yang diberikan baik secara langsung maupun tidak langsung. Manfaat langsung yaitu apabila suatu negara 
memproduksi barang dengan spesialisasi maka dapat mengekspor dengan biaya relatif rendah.

Kondisi ini akan memberikan keuntungan berupa peningkatan pendapatan nasional yang juga meningkatkan jumlah output dan akhirnya menciptakan pertumbuhan ekonomi. Sedangkan manfaat tidak langsung berupa peningkatan pemakaian teknologi, mendorong inovasi, meningkatkan produktivitas buruh, menurunkan biaya produksi.

Penelitian yang dilakukan oleh Prihartanti (2007) yang berjudul "Analisis Faktorfaktor yang Memengaruhi Penyerapan Tenaga Kerja Sektor Industri di Kota Bogor" menunjukkan bahwa faktor-faktor yang signifikan memengaruhi penyerapan tenaga kerja pada sektor industri di Kota Bogor adalah upah riil, investasirill, jumlah unit usaha. Upah riil berpengaruh negatif terhadap penyerapan tenaga kerja sektor industri. Peningkatan upah di sektor industri yang tidak disertai dengan meningkatnya penerimaan yang diperoleh perusahaan akan menyebabkan penyerapan tenaga kerja di sektor industri menurun.Peningkatan nilai investasi akan meningkatkan jumlah perusahaan yang bergerak pada sektor industri sehingga menimbulkan peningkatan penyerapan akan tenaga kerja pada sektor industri. Dengan semakin banyaknya investor di Kota Bogor akan menyebabkan terjadinya peningkatan penyerapan tenaga kerja pada sektor industri. Bertambahnya jumlah unit usaha yang ada di Kota Bogor mengakibatkan semakin meningkatnya jumlah penyerapan tenaga kerja di sektor tersebut.

Hasil penelitian Kagami (2000) tentang perubahan struktur ekonomi dan kesempatan kerja sektor pertanian dan non pertanian di Sumatera Selatan menunjukkan bahwa kesempatan kerja sektor industri dipengaruhi oleh upah sektor industri, investasi sektor industri, jumlah perusahaan perindustrian, PDRB sektor industri, dan kesempatan kerja sektor pertanian. Analisis lebih lanjut menjelaskan bahwa kesempatan kerja sektor industri dipengaruhi secara nyata oleh variabel kesempatan kerja sektor pertanian. Sedangkan kesempatan kerja sektor industri tidak responsif terhadap tingkat upah, PDRB, dan Jumlah Perusahaan. Keluar masuknya tenaga kerja sektor industri tidak terlampau dipengaruhi oleh perubahan variabel-variabel tersebut.

Fudjaja (2002) melakukan penelitian tentang dinamika kesempatan kerja sektor pertanian dan industri di Sulawesi Selatan. Hasil penelitiannya menemukan faktorfaktor yang memengaruhi kesempatan kerja sektor industri antara lain kesempatan kerja sektor pertanian, PDRB sektor industri tahun sebelumnya, jumlah perusahaan industri, angkatan kerja, dan kesempatan kerja sektor industri tahun sebelumnya.

Penelitian Wicaksono (2009) melakukan analisis pengaruh PDB sektor industri, upah riil, suku bunga riil, dan jumlah unit usaha terhadap penyerapan tenaga kerja pada industri pengolahan sedang dan besar di Indonesia tahun 1990-2008. Hasil analisisnya menunjukkan bahwa penyerapan tenaga kerja pada sektor industri pengolahan dipengaruhi secara signifikan oleh PDB sektor industri dan upah riil.Kedua variabel tersebut berpengaruh positif terhadap penyerapan tenaga kerja sektor industri. Berdasarkan dari latar belakang diatas Ketertarikan terhadap penelitian "Pengaruh ekspor minyak mentah,batubara dan gas alam terhadap penyerapan tenaga kerja sektor pertambangan di Indonesia"

\section{METODE}

Data yang digunakan dalam penelitian ini adalah data sekunder runtun waktu selama periode Tahun 1993 - 2015, yang mencukup data jumlah tenaga kerja sektor pertambangan di Indonesia, ekspor minyak mentah Indonesia, ekspor batubara Indonesia, ekspor gas alam Indonesia. Sumber data utama berasal dari Asian Development Bank (ADB). 
Data dianalisis secara deskriptif dan model regresi berganda OLS dengan persamaan sebagai berikut:

\section{$\mathbf{T k}=\beta_{0}+\beta_{1} X m+\beta_{2} X b b+\beta_{3} X g a+\varepsilon$}

Dimana:

$\mathrm{Xm}=$ Volume ekspor minyak mentah $\mathrm{Tk}=$ Tenaga kerja sektor pertambangan

$\mathrm{Xbb}=$ Volume ekspor batubara $\quad \mathrm{Xga}=$ Volume ekspor gas alam

$$
\varepsilon=\text { error term }
$$

\section{HASIL DAN PEMBAHASAN}

\section{Perkembangan tenaga kerja Indonesia di sektor pertambangan}

Untuk mengetahui perkembangan tenaga kerja Indonesia di sektor pertambangan selama thaun 1993 sampai 2015 dapat dilihat pada Gambar 1. Berdasarkan data pada Gambar 1 terlihat bahwa rata-rata pertumbuhan tenaga kerja Indonesia di sektor pertambangan selama tahun 1993 sampai tahun 2015 adalah 4,45\% dengan pertumbuhan tertinggi terjadi pada tahun 2004 yakni 41,20 \% dan pertumbuhan terendah terjadi pada tahun 2000 yakni $-27,96 \%$.

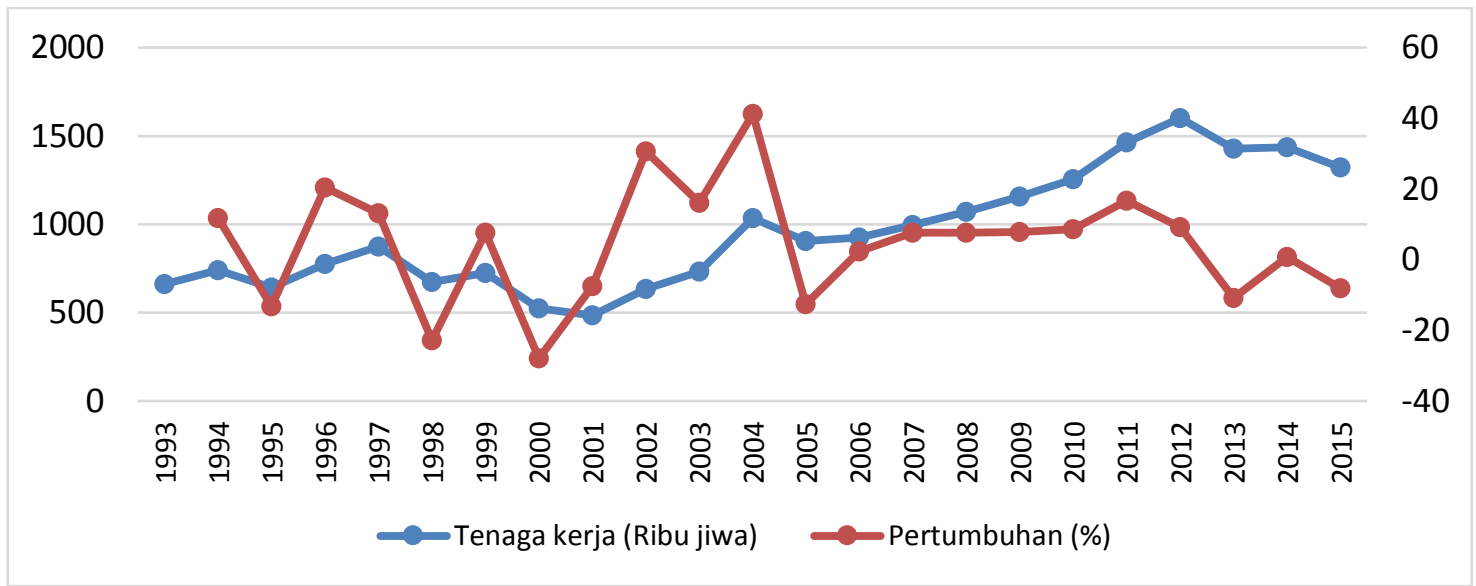

Gambar 1. Perkembangan tenaga kerja Indonesia sektor pertambangan

Sumber : Asian Development Bank

\section{Perkembangan ekspor minyak mentah Indonesia}

Untuk mengetahui perkembangan ekspor minyak mentah Indonesia periode tahun 1993 sampai tahun 2015 dapat dilihat pada Gambar 2

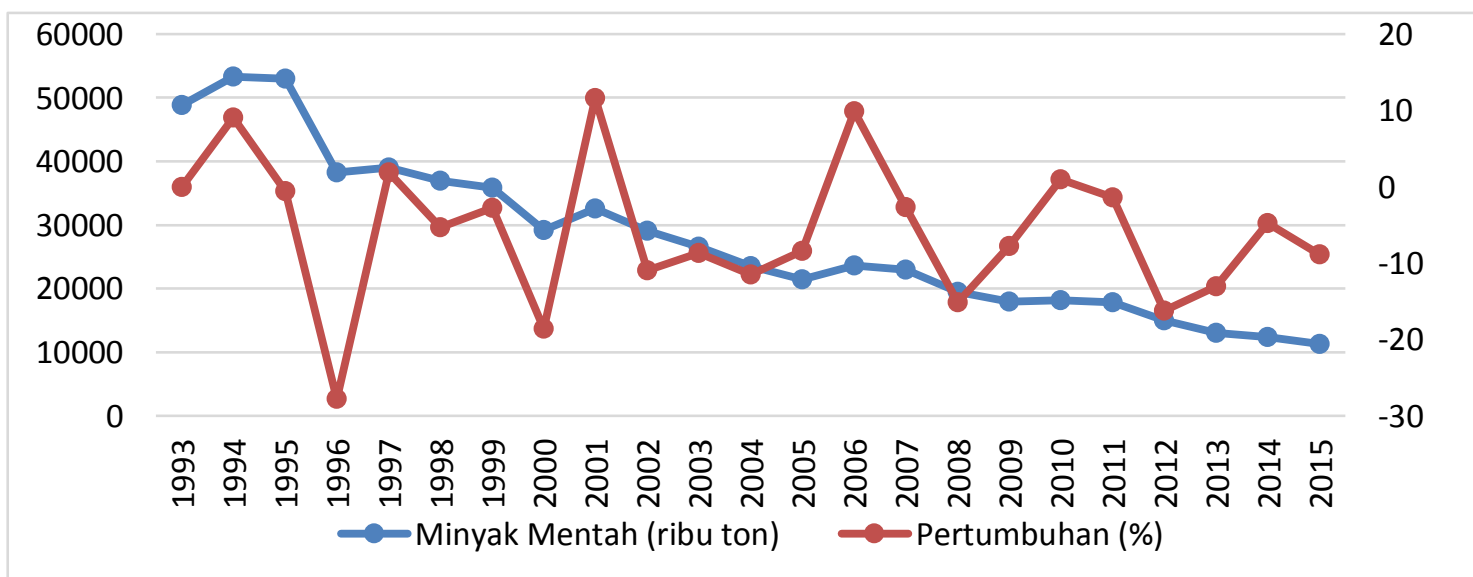

Gambar 2. Perkembangan ekspor minyak mentah Indonesia periode tahun 1993-2015

Sumber : Asian Development Bank 
Berdasarkan data pada Gambar 2 terlihat bahwa selama periode tahun 1993 sampai tahun 2015 volume ekspor minyak mentah cendrung mengalami penurunan dengan rata-rata $-4,73 \%$ dengan pertumbuhan terendah terjadi pada tahun 1996 yakni $27,82 \%$ dan pertumbuhan tertinggi terjadi pada tahun 2001 yakni $11,6 \%$.

\section{Perkembangan ekspor batubara Indonesia}

Untuk mengetahui perkembangan ekspor batubara Indonesia selama tahun 1993 sampai tahun 2015 dapat dilihat pada Gambar 3.

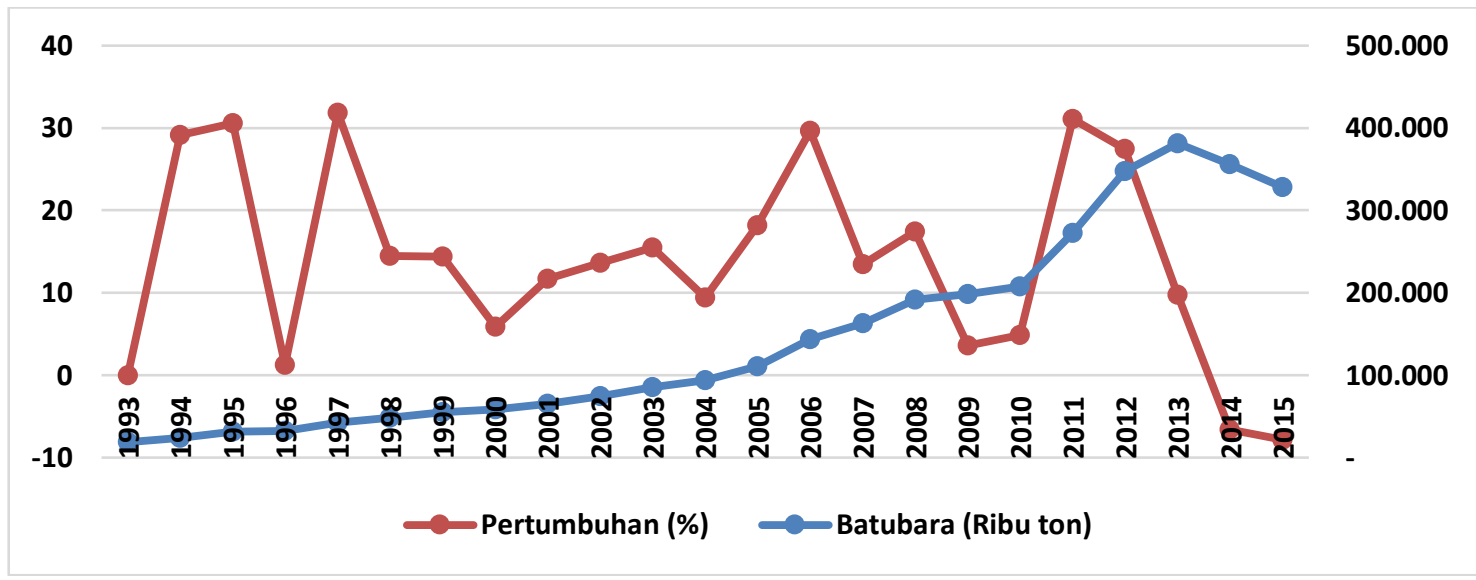

Gambar.3. Perkembangan ekspor batubara Indonesia tahun 1993 sampai tahun 2015 Sumber : Asian Development Bank

Berdasarkan informasi pada Gambar 3 terlihat bahwa volume ekspor batubara Indonesia kecendrungannya mengalami peningkatan selama periode tahun 1993 sampai tahun 2015 dengan rata-rata pertumbuhannya sebesar 14,49\% dengan pertumbuhan tertinggi terjadi pada tahun 1997 yakni sebesar 31,85\% dan pertumbuhan terendah terjadi pada tahun 2015 yakni sebesar $-7,83 \%$.

\section{Perkembangan eskpor gas alam Indonesia}

Untuk mengetahui perkembangan ekspor gas alam Indonesia selama periode tahun 1993 sampai tahun 2015 dapat dilihat pada Gambar 4.

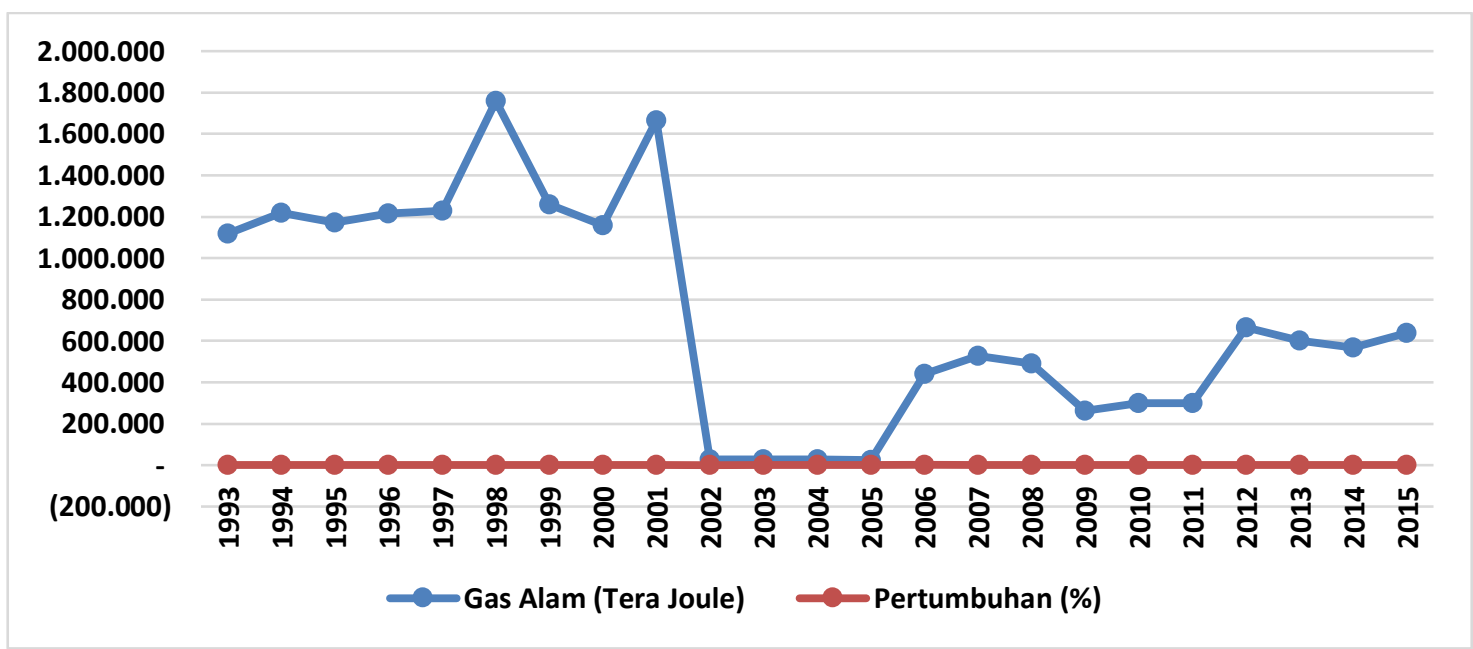

Gambar 4. Perkembangan ekspor gas alam Indonesia selama periode tahun 1993 - 2015 Sumber : Asian Development Bank

Berdasarkan informasi Gambar 4. dapat diketahui bahwa selama periode tahun 1993 sampai tahun 2015 volume ekspor gas alam kecendrungannya mengalami peningkatan dengan rata-rata pertumbuhan sebesar 79,54\%. Pertumbuhan tertinggi 
terjadi pada tahun 2006 yakni sebesar $1700,47 \%$ dan pertumbuhan terendah terjadi pada tahun 2002 yakni $-98,34 \%$.

\section{Pengaruh ekspor minyak mentah, batubara dan gas alam terhadap penyerapan tenaga kerja Indonesia di sektor pertambangan}

\section{Estimasi model}

Estimasi model pengaruh ekspor minyak mentah ,batubara dan gas alam dapat dilihat pada tabel 1 .

Tabel 1. Estimasi model pengaruh ekspor minyak mentah ,batubara dan gas alam terhadap tenaga kerja sektor pertambangan

\begin{tabular}{lrlrr}
\hline \multicolumn{1}{c}{ Variable } & Coefficient & Std. Error & t-Statistic & \multicolumn{1}{c}{ Prob. } \\
\hline C & 439.5406 & 172.5594 & 2.547184 & 0.0197 \\
BATUBARA & 0.002918 & 0.000436 & 6.694989 & 0.0000 \\
GASALAM & -0.000116 & $6.65 \mathrm{E}-05$ & -1.742610 & 0.0976 \\
MMENTAH & 0.006509 & 0.004789 & 1.359045 & 0.1900 \\
\hline R-squared & 0.874621 & Mean dependent var & & 958.9565 \\
Adjusted R-squared & 0.854825 & S.D. dependent var & 328.8399 \\
S.E. of regression & 125.2942 & Akaike info criterion & 12.65598 \\
Sum squared resid & 298274.2 & Schwarz criterion & & 12.85345 \\
Log likelihood & -141.5437 & F-statistic & & 44.18027 \\
Durbin-Watson stat & 1.161733 & Prob(F-statistic) & & 0.000000 \\
\hline Surbit
\end{tabular}

Sumber: Data diolah, 2018

\section{Uji simultan (uji F)}

Dari data pada Tabel 1 diperoleh nilai F hitung 44.18 dengan probabilitas 0,000. Artinya secara bersama-sama variabel ekspor minyak mentah, ekspor batubara dan ekspor gas alam berpengaruh signifikan terhadap penyerapan tenaga kerja di sektor pertambangan. Selanjutnya, berdasarkan nilai $\mathrm{R}$ square sebesar 0,87 artinya $87 \%$ perubahan tenaga kerja sektor pertambangan dipengaruhi oleh variabel ekspor batubara,minyak mentah dan gas alam,

\section{Uji parsial (uji t)}

Variabel ekspor batubara menunjukkan hasil positif dan signifikan dalam mempengaruhi penyerapan tenaga kerja di sektor pertambangan. Komoditas batubara saat ini di Indonesia pertambangannya sangat meningkat hal ini terlihat dari rata-rata peningkatan ekspor batubara selama tahun 1993 sampai 2015 yakni 14,49\%. Dengan meningkatnya tambang produksi batubara maka kebutuhan akan tenaga kerja juga semakin meningkat karena komoditas batubara tidak terlalu membutuhkan ketrampilan tertentu dari tenaga kerjanya sehingga tenaga kerja yang memiliki tingkat pendidikan rendah pun juga bisa bekerja di sektor ini.

Sementara untuk komoditas gas alam menunjukkan hasil yang berbeda arah pengaruhnya dibandingkan dengan komoditas batubara. Pada komoditas gas alam menunjukkan pengaruh yang negatif dan signifikan terhadap penyerapan tenaga kerja di sektor pertambangan. Hal ini mengindikasikan bahwa walaupun secara produksi gas alam Indonesia terus meningkat dengan indikasi rata-rata peningkatan ekspor $79,54 \%$ selama periode tahun 1993 sampai 2015 namun input atau faktor produksi yang digunakan untuk mengolah komoditas gas alam ini memiliki spesialisasi dan faktor produksi yang langka seperti sumber daya manusia dan sumber daya modal dan teknologi yang sebagian masih membutuhkan impor dari luar negeri dan bantuan investor asing sehingga berdampak pada turunnya serapan tenaga kerja lokal di sektor pertambangan.

Komoditas minyak mentah tidak berpengaruh signifikan terhadap serapan tenaga kerja di sektor pertambangan. Hal ini disebabkan kecendrungan ekspor minyak mentah 
yang semakin turun yang dapat dilihat dari rata-rata penurunan ekspor minyak mentah selama periode tahun 1993 sampai tahun 2015 yakni -5,96\% dan faktor produksi yang digunakan oleh komoditas minyak mentah juga memiliki spesialisasi keahlian tertentu sehingga tidak semua tenaga kerja yang bisa bekerja di sektor ini.

\section{KESIMPULAN DAN SARAN}

\section{Kesimpulan}

Penyerapan tenaga kerja Indonesia di sektor pertambangan kecendrungannya mengalami peningkatan dengan rata-rata $4,45 \%$ sementara volume ekspor minyak mentah cendrung mengalami penurunan dengan rata-rata sebesar $-5,96 \%$ kemudian untuk komoditas batubara cendrung mengalami peningkatan dengan rata-rata pertumbuhan sebesar $14,49 \%$ dan untuk komoditas gas alam volume ekspornya cendrung mengalami peningkatan dengan rata-rata sebesar 79,54\%.

Berdasarkan hasil regresi menunjukkan bahwa volume ekspor komoditas batubara berpengaruh positif dan signifikan terhadap penyerapan tenaga kerja di sektor pertambangan sementara volume ekspor komoditas gas alam berpengaruh negatif dan signifikan terhadap penyerapan tenaga kerja sektor pertambangan, dan volume ekspor komoditas minyak mentah tidak berpengaruh signifikan terhadap penyerapan tenaga kerja di sektor pertambangan.

\section{Saran}

Pemerintah diharapkan dapat meningkatkan upaya-upaya untuk eksplorasi area pertambangan baru khususnya komoditas batubara dan gas alam. Selain bertujuan untuk meningkatkan ekspor juga dalam rangka meningkatkan kesempatan kerja.

\section{DAFTAR PUSTAKA}

Ananta, A. (1985). Masalah Penyerapan Tenaga Kerja,Prospek dan permasalahan ekonomi Indonesia. Sinar Harapan: Jakarta

Asian Development Bank. (2013). Key Indicators For Asia and Pasific 2013. Asian Development Bank Statistics.

Badan Pusat Statistik . (2013).Indonesia dalam Angkat: Jakarta

Desnky. R, Syaparuddin, Siti.A. (2018) Ekspor kopi Indonesia dan faktor-faktor yang mempengaruhinya, Jurnal Perdagangan, Industri dan Moneter, 6(1),23-34

Fudjaja, L. (2002) Melakukan penelitian tentang dinamika kesempatan kerja sektor pertanian dan industri di Sulawesi Selatan.Tesis.IPB: Bogor

Haryadi, (2007). Ekonomi Internasional Teori dan Kebijakan. Biografika: Bogor

Juanda, B., Junaidi. (2012). Ekonometrika Deret Waktu (Teori dan Aplikasi),PTPenerbit IPB Press:Bogor.

Kagami, H. (2000). Tentang Perubahan Struktur Ekonomi dan Kesempatan Kerja Sektor Pertanian dan Non Pertanian di Sumatera Selatan,Tesis,IPB,Bogor: Bogor

Pratama, D. (2012). Analisis Pertumbuhan Penyerapan Tenaga Kerja Pada Industri Kecil di Kabupaten Jepara. Skripsi.Fakultas Ekonomika dan Bisnis Universitas Diponegoro: Semarang

Prihartanti, E.D. (2007). Analisis Faktor-faktor yang Memengaruhi Penyerapan Tenaga Kerja Sektor Industri di Kota Bogor,Skripsi,Departemen Ilmu Ekonomi,IPB: Bogor

Wicaksono, R. (2009). Analisis Pengaruh PDB Sektor Industri, Upah Riil, Suku Bunga Riil, Dan Jumlah Unit Usaha Terhadap Penyerapan Tenaga Kerja Pada Industri Pengolahan Sedang Dan Besar di Indonesia Tahun 19902008.Skripsi. FE-UNDIP: Semarang. 